\title{
Oversight on the Constitutionality of Laws: A Case Study of the Jordanian Constitutional Court
}

\author{
Dr. Hazem Suleiman Toubat* \\ Assistant Professor at Jadara University, School of law. Irbid, Jordan \\ Dr. Emran mahafzah \\ Associated Professor at Jadara University, School of law. Irbid, Jordan \\ Dr. Hashim Ahmed Balas \\ Lawyer at the Jordanian Bar Association
}

\begin{abstract}
This study aims to examine the oversight on the constitutionality of laws in Jordan in the light of the relevant constitutional provisions. The doctrinal approach is used in this study, where the primary data were collected through the provisions of the Jordanian Constitution and laws as well as the ruling of the Jordanian constitutional court. The study addresses the importance of the oversight on the constitutionality of laws, the provisions of the Jordanian Constitution relating to the Constitutional Court, and then the decisions and rulings of the constitutional court.The study concluded that the legal and constitutional provisions relating to the Jordanian Constitutional Court, , together with the Court's commitment to formal procedures have negatively affected the Court's role in monitoring the constitutionality of laws and its presumed role in protecting the rights and freedom of Jordanians. Keywords: Jordan, Jordanian Constitution; Constitutional Court; Constitutionality of Laws.
\end{abstract}

DOI: $10.7176 / J L P G / 82-03$

\section{Introduction}

The oversight on the constitutionality of laws constitutes an important element in the formation of the legal state, which is based on the principle of the rule of law and respect for the rights and freedoms of citizens. ${ }^{1}$ This principle principle is based on the fact that the Constitution is the fundamental law on which the legal and political system of any country is built. Thus, the Constitution is superior to other legislations. As a result, the constitutional rules can only be repealed or amended by a similar constitutional rule. It also means that the legal rules may not be explicitly or implicitly contrary to constitutional rules, whether in text, content, or objectives. Otherwise, these legal rules become unconstitutional and must be judged null and void. ${ }^{2}$

The function of monitoring the constitutionality of laws is usually entrusted to a neutral, independent and specialized entity, which controls acts of the legislature. Thus, this entity constitutes the true protector of the Constitution in terms of form and content. In Jordan, this function is entrusted to the constitutional court, where Article 58 of the Jordanian Constitution states "A Constitutional Court shall be established by a law and based in Amman and shall be deemed an independent and separate judicial body".

This study examines the effectiveness of the Jordanian Constitutional Court in monitoring the constitutionality of laws in the light of the relevant constitutional provisions, in addition to its role in protecting the rights and freedoms of Jordanians. It clarifies first the concept and importance of the oversight on the constitutionality of the laws. It then addresses the oversight on the constitutionality of laws in Jordan in the light of the establishment of the Constitutional Court.

\section{Importance of the Oversight on the Constitutionality of Laws}

The envisaged purpose of adopting the oversight on the constitutionality of laws is to ensure the principle of supremacy of the Constitution, which is the real guarantor of rights and freedoms ${ }^{3}$ It is therefore a valuable means means of promoting human rights and achieving justice. ${ }^{4}$ Hence, the importance of oversight on the constitutionality of laws can be summarized as follows:

\section{1 Protecting the Democratic System and the Rule of the Constitution}

The oversight of the constitutionality of laws is one of the pillars of the democratic system, whereby the democracy requires the existence of legislative authority to undertake the task of enacting laws. It also requires the existence

\footnotetext{
1 Ali Mohammed. "The Requirements of Activating the Supervision of the Constitutionality of Laws under the Constitutional Amendments: (Algeria and Morocco model)." Journal of Law and Society (ASJP). Vol 1, (8), 120-141.2016

2 Ibrahim Sheha. Political Systems and Constitutional Law, 3ed. (Alexandria: Manshaat Al Ma'aref, 2000$).$ P205.

${ }^{3}$ Ibrahim Sheha. Ibid.p 272.

${ }^{4}$ Laith Nasrawin. "Protecting Human Rights Through Constitutional Adjudication - Jordan as a Case Study." Digest of Middle East Studies, Wiley Online Library. Volume 25, 2. 2016. 264-284.
} 
of a judicial body to interpret the provisions of the law, and to ensure that the provisions of the Constitution are not violated. ${ }^{1}$

The laws are supposed to be compatible with the Constitution, which requires the existence of a Constitutional Court to monitor the constitutionality of these laws. Establishing the Constitutional Court will lead to protect the principle of the rule of law, and the establishment of a democratic state where rights and freedoms are respected. ${ }^{2}$ This is because democracy cannot be an effective reality, only in a country that has effective oversight on the constitutionality of laws. Such oversight must be carried out by an independent constitutional body to repeal any legislation inconsistent with the will of the people expressed in the Constitution. ${ }^{3}$

Some French jurists consider the oversight on the constitutionality of laws to be an inevitable consequence of the principle of separation of powers. Just as the Judiciary is not allowed to infringe upon the jurisdiction of the legislature, the Legislative Authority may not be allowed to interfere in the jurisdiction of the Judiciary ${ }^{4}$ If the Legislative Authority allows itself to enact a law that contradicts the Constitution, the Judiciary should not be forced to participate in the legislative violation of the Constitution through the application of the violating law. Such coercion is considered an infringement of the jurisdiction of the Judiciary by the legislature. Therefore, there must be an independent body to decide the constitutionality of these laws. ${ }^{5}$

\subsection{Ensure Respect for the Rights and Freedoms}

The oversight of the constitutionality of laws aims to verify that the legislator is exercising his function within a constitutionally permissible range. This means inevitably forcing the legislator to respect rights and freedoms, since the constitution is the guarantor of these rights. ${ }^{6}$ The authority of Parliament, in the absence of being subject to constitutional control, is considered extremely dangerous. It may push Parliament to enact laws that are not consistent with the spirit of the constitution and its provisions, which violates the essence of rights and freedoms. ${ }^{7}$

All constitutions, including the Jordanian Constitution, did not address all rights and freedoms in the same way. There are certain rights that are regulated by laws enacted by the legislature according to its discretionary authority, which requires constitutional control over this legislation. This control must be carried out by a specialized and independent body. This body should ensure that the legislature does not exceed the constitutional controls when exercising its discretionary authority in regulating the exercise of rights and freedoms. Thus, the oversight of the constitutionality of laws is a mainstay and a fundamental protection of rights and freedom, and therefore, transferring the constitutional provisions protecting the rights and freedoms from the theoretical text to practical reality. ${ }^{8}$

\subsection{Achievement of the Political and Legal Stability}

Oversight of the constitutionality of laws will undoubtedly lead to political and legal stability in the state, ${ }^{9}$ where the views may differ around the constitutionality of some provisions of laws and regulations. In such a case, it would be necessary to resort to a body with a constitutional competence to adjudicate this dispute. Thus, oversight of the constitutionality of laws leads to the avoidance of legislative chaos and legal stability, as well as the settlement of disputes over the rights and legal status established by law. ${ }^{10}$

Since the ordinary courts may consider disputes that may be governed by different laws, in this case, it is necessary to have a Constitutional Court to determine the meaning of the Constitution and to link all laws to the Constitution. Thus, the unity of the legal system, which the Constitution stands at the top, is maintained, and then, achieving the legal stability based on the principle of the supremacy of the Constitution. ${ }^{11}$ Therefore, the oversight on the constitutionality of laws leads to the unity and cohesion of the legal system and the harmony of laws with the Constitution. This enables the provisions of the Constitution to be reflected in all laws to make these laws an integral part of the Constitution. The legal system is diverse in its branches, means, and protected interests, but all should be under the umbrella of the Constitution and subject to uniform constitutional principles. ${ }^{12}$

\footnotetext{
${ }^{1}$ Muddather Abu- Karaki, Raed S. A Faqir and Majed Ahmad K. Marashdah. "Democracy and Judicial Controlling in Jordan: A Constitutional Study." Journal of Politics and Law, 4(2), 180-195. doi:10.5539/jpl. v4n2p180. 2011.

2 Laith Nasrawin. Ibid.

${ }^{3}$ Bojan Bugarič. "Protecting Democracy and the Rule of Law in the European Union: The Hungarian Challenge." LSE 'Europe in Question' Discussion Paper Series, LEQS Paper No. 79/2014. 2014. http://www. 1se.ac.uk /europeanInstitute/LEQS/LEQSPaper79.pdf.

4 Ali Shatnawi. The Jordanian Constitutional System, $3^{\text {rd }}$ ed. (Amman, JO: Dar Wa'el. 2013).

Ibrahim Sheha, Ibid. p 272

6 Ali Mohammed. Ibid.

7 Faisal Shatnawi. Human Rights and International Humanitarian Law.Ibid. p 227.

8 Muddather Abu- Karaki, Raed S. A Faqir and Majed Ahmad K. Marashdah. Ibid.

9 Faisal Shatnawi. Human Rights and International Humanitarian Law. Ibid. p 227.

${ }^{10}$ Naji Makki. Director General of the Federal Supreme Court of Iraq. Philosophical Foundations for the Control of the Constitutionality of Proposed Laws and Constitutional Amendments, Research Paper, University of Baghdad: Center for Strategic Studies, 2009.

11 Faisal Shatnawi. Human Rights and International Humanitarian Law. Ibid. p 228.

12 Abdul Ghani Bassiouni. Ibid. p176.
} 


\section{The Evolution of the Oversight on the Constitutionality of Laws in Jordan}

The Jordanian Constitution, before 2011, did not include any provisions relating to the oversight of the constitutionality of laws. It had provided for the existence of the Higher Council for the Interpretation of the Constitution, which was abolished under the 2011 constitutional amendments. The mission of this Council was confined to the interpretation of the provisions of the Constitution. It was also tasked to prosecute Ministers in criminal offenses arising from the performance of their jobs; however, it was not authorized to oversee the constitutionality of laws.

Oversight of the constitutionality of laws and regulations was taken over by the Judiciary after initially refraining from doing so. The refraining was justified by the fact that there was no explicit constitutional provisions authorizing or preventing it from undertaking such a task. ${ }^{1}$ Therefore, the attitude of the Judiciary in this regard was confused, and characterized by instability. ${ }^{2}$ It had been giving itself the right to oversee the constitutionality of laws in some cases and deny itself this right in other cases, where the Judiciary was only abstaining from applying the provisions that are contrary to the Constitution in the cases before it, without giving itself the right to repeal these provisions. ${ }^{3}$ In such a situation, of the absence of a competent authority to consider the constitutionality of laws and fluctuation of the attitude of the ordinary courts in this matter, the need arose to stipulate explicitly the presence of a competent authority in this domain.

When the Jordanian Constitution was amended in 2011, a whole chapter (Chapter 5) was added to the Constitution under the title 'Constitutional Court'. The provisions of this chapter included the establishment of an independent judicial body named the Constitutional Court to be located in the capital, Amman City. ${ }^{4}$

\section{The Constitutional Provisions Relating to the Jordanian Constitutional Court}

The Jordanian Constitution, in Articles 58-61, provides general provisions concerning the Constitutional Court . Under Article 58, the Jordanian Constitution entrusts the Constitutional Court the task of overseeing the constitutionality of the applicable laws and regulations and to interpret the provisions of the Constitution. ${ }^{5}$ The Constitution also provides for the provisions of the formation of the Constitutional Court, its characteristics, jurisdiction, and mechanism for recourse to the Constitutional Court.

\subsection{Formation of the Constitutional Court}

According to the provisions of Article 58 of the Constitution, the Constitutional Court shall consist of at least 9 members, including the president, appointed by the King. As for the details of its formation, it has been referred, by the Constitution, to the Legislative Authority to be regulated by law. The Constitution stipulates that this Court shall be independent and detached from the authorities of the state. ${ }^{6}$

Article 5 of the Constitutional Court Law of $2012^{7}$ determines the maximum limit for the number of members of the Constitutional Court at 15. The Court was composed, when the beginning of its establishment in 2012 of 9 members, including the President, then, 3 members were appointed after two years (in 2014) to reach 12, and then 3 other members were appointed after two more years (in 2016), bringing the total number to 15 .

\subsection{Terms of Membership in the Constitutional Court}

According to the provisions of Article 61 of the Jordanian Constitution and Article 6 of the Constitutional Court Law of 2012, a person who appointed a member of the Constitutional Court shall meet the following conditions: ${ }^{8}$ a. To be Jordanian and not to hold any other nationality.

b. To have attained the age of 50 .

c. To be of any of the following categories; who served as judges in the Supreme Court of Justice and the Court of Cassation whether employed or retired, of law Professors in universities, of the lawyers who spent a period of not less than 15 years in the practice of law, whereas, one of a member of the Court shall be a specialist who meets the conditions of membership in the Senate.

The members of the Court may not be seconded or appointed to work for any party during the term of membership in the Court. The members must also be fully engaged in the work of the Court. They should not be an employee in the public or private sector or occupy any position in these sectors. In addition, they may not engage in any commercial activity or be a chairperson or member of the board of directors of any private or public

\footnotetext{
1 The Court of First Instance of Amman. Resolution No. (91/66). Dated September 26, 1966; . Resolution No. (230/74) Dated March 12, 1974. 2 No'man AL-Khatib. AL-Wasset (the Mediator) in the Political Systems and Constitutional Law. $7^{\text {th }}$ ed. (Amman: Dar Al Thaqafa for Publishing and Distribution). ISBN 9957-16-119-9. 2011.

${ }^{3}$ Muddather Abu- Karaki, Raed. S. Faqir and Majed Ahmad K. Marashdah. Ibid.

4 Jordanian Constitution, Article 58, Paragraph 1.

5 Jordanian Constitution, Article 59.

6 Jordanian Constitution, Article 58:1, Paragraph.2.

7 The Constitutional Court Law No. 15 of 2012.Article 5. Published on Official Gazatte (Al Jarida Al Rasmiyya) in June 7, 2012, No. 5161, P. 2519 - P.2528

8 Jordanian Constitution, Article 61
} 
company. In addition, they must not associate with any political party. ${ }^{1}$

It is clear that the Constitution does not require all the judges of the Constitutional Court to have an exclusive judicial background, but it is enough that some of them have served as judges in the Supreme Court of Justice or the Court of Cassation. Meanwhile, all members of the Court shall have a legal background with the exception of one member, who shall meet the conditions of membership in the Senate. Once appointed in the Court, all members take the description as a judge.

\subsection{Duration of the Membership}

The Jordanian Constitution has set the period of membership in the Constitutional Court to 6 non-renewable years, whereas the Constitutional Court Law has clarified the cases of termination of membership in the Court. These cases are limited to the death, resignation, or recommendation from other members. The resignation comes into force after the issuance of a Royal Decree to accept it. The membership may also be terminated by Royal Decree based on a recommendation of 6 other members of the Court in any of the following cases: ${ }^{2}$

1. Loss of any of the membership conditions stipulated in the law.

2. Issuing permission from the rest of the members of the Court to prosecute the member in accordance with the provisions of Paragraph (b) of Article 23 of the Constitutional Court Law unless the crime committed by the member is an unintentional misdemeanor or an infraction. ${ }^{3}$

3. The health deficit that prevents him from performing his duties.

4. Loss of civil capacity.

In such cases, if the number of members of the Court becomes less than 9 , an alternate member shall be appointed to complete the remaining term of the terminated members.

\subsection{Characteristics of the Constitutional Court}

According to Article 58 of the Jordanian Constitution, the Constitutional Court is a self-contained independent judicial body. It is separated from the Judiciary. Thus, it is in line with what the Austrian Jurist, Hans Kelsen, called for, ${ }^{4}$ where he established the idea of abstract and specialized constitutional adjudication, calling for the need for the constitutional adjudication to be independent.

According to Article 3 of the Constitutional Court Law, the Jordanian Constitutional Court must have a legal personality, and shall enjoy the financial and administrative independence. In such capacity, it can own movable and immovable property and shall carry out all legal acts that are necessary for the performance of its functions. The Civil Attorney General shall represent it in judicial proceedings. ${ }^{5}$

\subsection{The Jurisdiction of the Constitutional Court}

The Jordanian Constitution and the Constitutional Court Law of 2012, define 2 functions for the Constitutional Court, which are: oversight on the constitutionality of applicable laws and regulations, and interpretation of the constitutional provisions. Meanwhile, the rulings of the Court shall be final and binding on all authorities and for all. These rulings shall also have a direct effect unless the judgment specifies another date for its enforcement. ${ }^{6}$

\subsubsection{Oversight on the Constitutionality of Applicable Laws and Regulations}

According to the provisions of Article 59 of the Constitution and Article 4 of the Constitutional Court Law, the oversight on the constitutionality of laws has become an exclusive jurisdiction of the Constitutional Court. ${ }^{7}$ Although this exclusivity is not explicitly stated either in the Constitution or in the Constitutional Court Law, it is implicitly understood through the indirect appeal mechanism established by the Constitution to challenge the constitutionality of the laws.

The Constitutional Court Law defines the role of the courts in this case by ascertaining the seriousness of the challenge of constitutionality or not, where its decision of non-referral shall be appealed along with the substance of the lawsuit. If the Court considers that the appeal of the constitutionality is serious, it shall stop considering the case and refer the appeal to the Court of Cassation. The role of the Court of Cassation, in this case, shall be to ascertain the seriousness of the appeal and then refer it to the Constitutional Court for consideration. ${ }^{8}$

The Constitutional Court Law defines the role assigned to the courts, including the Supreme Administrative Court and the Court of Cassation, in the case of raising the issue of the constitutionality. The courts cannot deviate from this specific role, meaning that the courts cannot consider the constitutionality of laws and regulations, so

\footnotetext{
1 The Jordanian Constitutional Court Law, Article 8

2 The Constitutional Court Law, Article 21.

${ }^{3}$ The Constitutional Court Law, Article 23

${ }^{4}$ Sara Lagi. "Hans Kelsen and the Austrian Constitutional Court (1918-1929)." Co-herencia 9, no. 16 (2012): $273-295$.

5 The Constitutional Court Law Article 3.

${ }^{6}$ Jordanian Constitution, Article 59.

${ }^{7}$ Jordanian Constitution, Article 59.

8 Jordanian Constitution, Article 60,
} 
that; this role is confined to the Constitutional Court. Therefore, if the courts find that the law is contrary to the Constitution, they cannot build on this view. What they have to do is to stop considering the case, and refer the appeal to the court specified in the law. Otherwise, if it decided that the law is consistent with the Constitution, it can make a decision to proceed with the case, such decision can be appealed. In the opposite sense, if the person who raised the appeal is satisfied with the decision of the Court and did not appeal this decision, the court's decision on the constitutionality of the law becomes effective and the appeal is not referred to the Court of Cassation.

\subsubsection{Interpretation of the Constitution}

The competence to interpret the provisions of the Constitution prior to the establishment of the Constitutional Court was vested in the Higher Council for the Interpretation of the Constitution, which was repealed under Paragraph 3 of Article 122 of the Constitution. ${ }^{1}$ This jurisdiction is confined now to the Constitutional Court alone. The Constitution specified the entities who can request the Constitutional Court to interpret the provisions of the Constitution. It is limited to 3 entities; the Council of Ministers, the House of Representatives, and the Senate. The jurisdiction of the Court is limited to interpreting the provisions of the Constitution only, in the sense that its competence does not include the interpretation of the provisions of laws or regulations.

\section{6 Mechanism for Recourse to the Constitutional Court}

Based on the entities requesting the Court to decide on the constitutionality of the law, the Jordanian Constitution sets out 2 mechanisms for recourse to the Court.

\section{6.1 Direct Recourse to the Constitutional Court}

The Jordanian Constitution has limited the entities that resort directly to the Constitutional Court in 3 exclusive entities, namely the Council of Ministers, the House of Representatives, and the Senate. ${ }^{2}$ If any of these 3 entities decide to challenge the constitutionality of any law or regulation, it shall submit an application signed by the head of the appellant entity to the Court. The application shall include clearly the name, number, and scope of the appealed law or regulation, and whether it concerns the whole law or regulation, or on one or more of its Articles. The application shall also indicate the grounds for violating the Constitution. ${ }^{3}$

The President of the Constitutional Court shall send a copy of the appeal, which is submitted to him by any of the 3 entities, to the President of each of the other 2 entities; either of them may submit his response to the Court within 10 days from the date of receipt of the appeal. The Court shall decide on the appeal within a period not exceeding 120 days from the date of its receiving. ${ }^{4}$

\subsubsection{Indirect Recourse to the Constitutional Court}

Indirect recourse to the Constitutional Court is in the cases heard by the ordinary courts. The Constitution allowed any party in a case before the courts to challenge the constitutionality of the law or regulation applicable to this case. The challenge shall be introduced to the same court that considers the case. If the court finds that the law or regulation that has been challenged is applicable to the subject of the case, and that the challenge of constitutionality is serious, it may refer it to the Court of Cassation or to the Supreme Administrative Court, depending on the type of case; civil, criminal or administrative case. If the court considering the case decides not to refer the plea to the Court of Cassation, its decision may be appealed along with its final resolution issued on the subject of the lawsuit. ${ }^{5}$

If the challenge of constitutionality is referred to the Court of Cassation, the Court of Cassation shall be held by a panel of at least 3 members and shall issue its decision within 30 days from the date of receipt of the application. If a decision is taken to refer the request to the Constitutional Court, in such case, it shall inform the parties about this decision. ${ }^{6}$

\section{Decisions and Rulings of the Constitutional Court}

The Constitutional Court was established by virtue of the Constitutional Court Law No. 15 of 2012, which came in implementation of the provisions of the Constitution on the establishment of the Constitutional Court. The first president and the members of the Constitutional Court were appointed by a Royal Decree in 2012, and they swore the constitutional oath before the King on October 6, 2012 to be the date on which the Court commenced its duties. ${ }^{7}$

The Constitutional Court until 2018 has issued 15 interpretive decisions and 21 judgements on the constitutionality of certain laws and regulations. ${ }^{8}$

\footnotetext{
1 Jordanian Constitution, Article 122. “

2 Jordanian Constitution, Article 60, Paragraph 1.

3 Constitutional Court Law, Article 9.

${ }^{4}$ Constitutional Court Law, Article 10.

5 Jordanian Constitution, Article 60, Paragraph 2

${ }^{6}$ Constitutional Court Law, Article 11.

${ }^{7}$ Official Website of the Constitutional Court, Documents of the Court: Decisions and Rulings of the Court http://cco.gov.jo/enus/aboutthecourt/ definitionofthecourt. aspx.(access date Mrch 3, 2018).

8 Official Website of the Constitutional Court. Ibid.
} 
The Investigative Press Unit at Radio Al Balad ${ }^{1}$ prepared a report concerning the Jordanian Constitutional Court's rulings. The report pointed out that the Constitutional Court refrained from considering more than twothird of the appeals submitted to it, (11 cases out of 16), while 9 appeals were rejected due to formalities. Meaning that the Constitutional Court itself has narrowed its scope of work through its commitment to formal procedures at the expense of content. For instance, the Court refused to consider the challenge of the constitutionality of the Election Law No. 25 of 2012 because of non-payment of the challenge fees. The Court in this decision refused to consider the constitutionality of a law, which is one of the most important laws affecting the rights of citizens due to not paying the prescribed fees, although this issue is controversial among judges, including the members of the Constitutional Court itself. ${ }^{2}$

The Court decided that "... refer to the file of challenge, it was found that, the Court of Appeal and then the Court of Cassation ruled in the appellant's application, and therefore referred the challenge to the Constitutional Court without paying the appeal fees, provided for in Article 2 of the Bylaw of Fees for the Appeal of Constitutionality of 2013." For this reason, the Court decided to reject the appeal in terms of procedures and resubmission of the appeal to its record."

A member of the Constitutional Court, Mohammed Ghazawi, ${ }^{3}$ in his dissenting opinion, said that the appeal of the constitutionality of the Election Law is exempt from payment of the fee, and therefore the referral to the Constitutional Court is correct. Accordingly, the Constitutional Court shall consider this appeal.

Moreover, in its ruling on the appeal against Article 5 of the Owners and Tenants Law No. 22 of 2011, which was referred to it by the Court of Cassation, the Constitutional Court decided to reject the appeal because of the lack of formal procedures. The Court justified its decision that the agency given to the lawyer who filed the appeal did not include permission for the lawyer to challenge constitutionality before the Constitutional Court. The member of the Court, Mohammed Ghazawi, did not agree with the Court's decision. In his dissenting opinion, he considered that the agency provided by the appellant is correct in accordance with the provisions of Article 834 and thereafter of the Jordanian Civil Law. The Court's commitment to formal procedures would result in the loss of the citizens' rights.

The Constitutional Court has dealt only with one case concerning rights and freedoms. This case is about the right to form unions. In this case, the Court issued its explanatory decision No. 6 of 2013, which was issued at the request of the Senate. This decision includes the interpretation of the provisions of Article 23 and Article 120 of the Constitution, where it has been decided that Article 23 and Article 120 of Jordanian Constitution allows civil servants who are subject to the Civil Service Bylaw to form their own unions. ${ }^{4}$

\section{Discussion and Analysis}

The Jordanian Constitutional Court was established to carry out the task of oversight of the constitutionality of the applicable laws and regulations, as well as interpreting the provisions of the Constitution. This task of the Constitutional Court is supposed to promote the principle of the supremacy of the Constitution and strengthen the principle of separation of powers, thereby protecting the citizens' rights and freedom.

By studying the provisions of the Jordanian Constitution relating to the Constitutional Court it is noted that the Jordanian Constitution provides for the appointment of the members of the Court by the Executive Authority. However, this leaves the question of the mechanism for appointing the members to the Constitutional Court Law. The provisions of this law are not sufficiently detailed and repeat generally what is stated in the Constitution. It does not specify the mechanism of the appointment of members. ${ }^{5}$ In addition, the appointment of all members of the Court by the Executive Authority makes the Court lose its independence and subjects it to government control, especially since the Jordanian Constitution provides that the Executive Authority is entrusted to the King and exercised through his Ministers. According to Nasrawin, ${ }^{6}$ there is still a gap in the selection of members of the Constitutional Court, and there are no obvious procedural provisions in the Constitutional Court Law with regard to the nomination process or any probable role for elected members in this respect.

The mechanism of recourse to the Constitutional Court was the subject of observation and criticism by some opinions. According to Hamouri, ${ }^{7}$ the constitutional provisions in this regard indicates a narrowing of the scope of

\footnotetext{
1 Saraya News Agency. The Constitutional Court Refuses to Consider Two Thirds of the Appeals Submitted to it on .July 25 , 2016. http://www.sarayanews.com/article/379133. (access date: October 16, 2017).

${ }^{2}$ Official Website of the Constitutional Court. Ruling No. (5) for the Year 2013 -Relating to the Election Law No. 25 of 2012. Published in Official Gazette: 5245. Date of Publication: 13/10/2013. Order number: 2013/5. Summary of the decision: By majority, the appeal is not accepted and rejected in term of form

${ }^{3}$ Official Website of the Constitutional Court. Ruling No. (5) For the Year 2013. Ibid.

${ }^{4}$ Official Website of the Constitutional Court. Interpreting Decision No. (6) of Year 2013. Order Number: 2013/6. Published in Official Gazette:

5238. Date of Publication: September 1, 2013. http://www.cco.gov.jo/ar-jo/\%

5 The Constitutional Court Law of 2012,Article 5.

6 Laith Nasrawin. Ibid.

7 Mohamed Hamouri. Constitutional Reforms in Jordan Need to be Reformed. Amman; Magazine of the Jordanian Bar Association, No. 7, 8 and 9, 2011.
} 
oversight on the constitutionality of laws. It not only denies individuals to resort to the Constitutional Court directly however it is more stringent, where the referral to the Constitutional Court is suspended on the approval of the court examining the case and then on the approval of the Court of Cassation. This means that the Court of Cassation is the entity that has the jurisdiction to accept the referral or not. Hamouri also added that the recourse to the Constitutional Court must be given to every interested party. The judges shall also have the right to challenge the constitutionality of laws and regulations on his own initiative, and such challenge shall be referred directly to the Constitutional Court.

The Jordanian Constitutional Court, in its current state, is a means of circumventing the philosophy of constitutional adjudication, where the entities who are allowed to resort to the Constitutional Court do not need the interpretation of this Court and are not affected by the unconstitutionality of the laws. The House of Representatives, for example, if it doubts that there is ambiguity in the legal provisions, can amend these provisions to be more clear and therefore does not resort to the Constitutional Court, as is the case with the Senate and the Council of Ministers. Accordingly, the civil society organizations and the unions should have the right to resort to the Constitutional Court.

With regard to indirect challenge before the Constitutional Court, this method requires the approval of the court that is considering the case and then the approval of the Court of Cassation. If the Court of Cassation refused to refer the appeal to the Constitutional Court, its decision is final and cannot be challenged. The Court of Cassation, with this absolute jurisdiction established by the Constitutional Court Law, seems to be a second constitutional court that has the right to decide on the challenge introduced before it about the constitutionality of law or regulation.

The decision of the Court of Cassation, to reject the referral of the challenge of constitutional of laws to the Constitutional Court, is a conclusive decision that cannot be challenged in any way. It may be considered an additional restriction on the freedom of individuals to submit the challenge before the Constitutional Court.

\section{Conclusion}

This study concludes that the legal and constitutional provisions relating to the mechanism of work of the Jordanian Constitutional Court, the formation of the Court, and the appointment of its members, together with the Court's commitment to formal procedures have negatively affected the Court's presumed role in enshrining the principle of the supremacy of the Constitution and the oversight on the constitutionality of the laws, specially the laws regulating the rights and freedom of Jordanians. The provisions relating to the formation of the Court and the appointment of its members have affected the independence of the Court and made it subordinate to the Executive Authority, whereas the provisions relating to the recourse to the Court have restricted the right to appeal to the Court to the extent limit.

Furthermore, the constitutional provisions requiring the approval of the court hearing the case have restricted the right to recourse to the court. Since there are special courts in Jordan that are formed by military judges such as the State Security Court. Since the independence of the court is questionable, and contradicts the principle of the independence of the judiciary, and fair trial standards. Thus, this court is considered an additional obstacle to recourse to the Constitutional Court in the cases considered by it, especially those relating to rights and freedoms. Consequently, the Constitutional Court can not be considered a real guarantee of rights and freedoms,

\section{References}

1. AL-Khatib, No'man. AL-Wasset (the Mediator) in the Political Systems and Constitutional Law. $7^{\text {th }}$ ed. (Amman: Dar Al Thaqafa for Publishing and Distribution). ISBN 9957-16-119-9. 2011.

2. Bassiouni, Abdul Ghani. Political Systems, Foundations of Political Organization, State-Government-Rights and Public Freedoms. Alexandria :University House, n.d.

3. Bugarič, Bojan. "Protecting Democracy and the Rule of Law in the European Union: The Hungarian Challenge.” LSE ‘Europe in Question’ Discussion Paper Series, LEQS Paper No. 79/2014. 2014. http://www. lse.ac.uk /europeanInstitute/ LEQS/ LEQSPaper79.pdf.

4. Hammouri, Mohammed. Constitutional Reforms in Jordan Need to be Reformed. Amman; Magazine of the Jordanian Bar Association, No. 7, 8 and 9, 2011.

5. Lagi, Sara. "Hans Kelsen and the Austrian Constitutional Court (1918-1929)." Co-herencia 9, no. 16 (2012): 273-295.

6. Makki, Naji. Director General of the Federal Supreme Court of Iraq. Philosophical Foundations for the Control of the Constitutionality of Proposed Laws and Constitutional Amendments, Research Paper, University of Baghdad: Center for Strategic Studies, 2009.

7. Mohammed, Ali. "The Requirements of Activating the Supervision of the Constitutionality of Laws under the Constitutional Amendments: (Algeria and Morocco model)." Journal of Law and Society (ASJP). Vol 1, (8), 120-141.2016

8. Muddather Abu- Karaki, Raed S. A Faqir and Majed Ahmad K. Marashdah. "Democracy and Judicial 
Controlling in Jordan: A Constitutional Study.” Journal of Politics and Law, 4(2), 180-195. doi:10.5539/jpl. v4n2p180. 2011.

9. Nasrawin, Laith. "Protecting Human Rights Through Constitutional Adjudication - Jordan as a Case Study." Digest of Middle East Studies, Wiley Online Library. Volume 25, 2. 2016. 264-284.

10. Official Website of the Constitutional Court, Documents of the Court: Decisions and Rulings of the Court http://cco.gov.jo/en-us/aboutthecourt/ definitionofthecourt. aspx.(access date Mrch 3, 2018).

11. Shatnawi, Ali. The Jordanian Constitutional System, 3rd ed. (Amman, JO: Dar Wa'el. 2013).

12. Shatnawi, Faisal. Human Rights and International Humanitarian Law. Study in the International and National Laws. Amman: Dar AL- Hamed for Publishing and Distribution. 2001.

13. Sheha, Ibrahim. Political Systems and Constitutional Law, 3ed. (Alexandria: Manshaat Al Ma'aref, 2000).

14. Saraya News Agency. The Constitutional Court Refuses to Consider Two Thirds of the Appeals Submitted to it..July 25, 2016. http://www. sarayanews. com/ article/ 379133. (access date: January 30, 2019). 